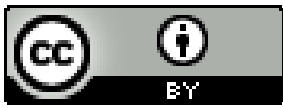

\title{
DESAFIOS PARA A IMPLEMENTAÇÃO DE UMA EDUCAÇÃO ANTIRRACISTA NO ENSINO DE GEOGRAFIA: OS CONFLITOS NA PRÁTICA COTIDIANA DE PROFESSORAS(ES)
}

\author{
Renato Emerson N. dos Santos ${ }^{1}$ \\ Ronald Coutinho Santos ${ }^{2}$
}

\begin{abstract}
Resumo: $\mathrm{O}$ artigo discute os desafios enfrentados no cotidiano escolar por professorxs de Geografia, na busca da implementação da Lei 10.639/03. A partir de uma leitura política das práticas dos docentes, analisa os conflitos em reação a propostas de conteúdos, atividades e posturas comportamentais em torno da temática racial. Assim, a implementação de uma educação antirracista - e, como parte dela, um ensino de Geografia que desafie discursos ainda hegemônicos calcados em racializações hierarquizantes -aparece como resultante de disputas pela interpretação da Lei 10.639/03, protagonizadas por docentes que enfrentam inércias e oposições (veladas e/ou abertas). O texto se baseia em depoimentos coletados em um processo de pesquisaação, através de reuniões mensais ao longo de cinco anos com docentes da rede pública (estadual e municipais) do Rio de Janeiro.
\end{abstract}

Palavras-Chave: Educação antirracista; Ensino de Geografia; Educação das Relações Raciais; Cotidiano escolar; Protagonismo docente.

\section{CHALLENGES FOR IMPLEMENTING AN ANTI-RACIST EDUCATION IN TEACHING GEOGRAPHY: CONFLICTS IN THE DAILY PRACTICE OF TEACHERS}

\begin{abstract}
The article discusses the challenges faced at school by Geography teachers in the search for the Law 10.639/03's implementation. Based on a political reading of the teachers' practices, it analyzes conflicts in reaction to proposals for content, activities and behavioral attitudes around racial issues. Thus, the implementation of an anti-racist

\footnotetext{
${ }^{1}$ Geógrafo, professor adjunto do IPPUR/UFRJ. Coordenador do Núcleo de Estudos e Pesquisas em Geografia, Relações Raciais e Movimentos Sociais (NEGRAM). Foi presidente da Associação dos Geógrafos Brasileiros (2012-2014), e já integrou o Conselho Fiscal da Associação Brasileira de Pesquisadores Negros (2004-2006). E-mail: renatoemerson@hotmail.com

${ }^{2}$ Mestre em Geografia pelo Programa de Pós-Graduação em Geografia da FFP-UERJ, Pesquisador do Núcleo de Estudos e Pesquisas em Geografia, Relações Raciais e Movimentos Sociais (NEGRAM), Coordenador do GT de Relações Raciais e Interseccionalidades da Associação dos Geógrafos Brasileiros - Seção Local Niterói. E-mail: ronald.coutinho@hotmail.com
} abril de 2020, p. 78-108 
education - and, as part of it, a teaching of Geography that challenges still hegemonic discourses based on hierarchical racializations - appears as a result of disputes over the interpretation of Law 10.639/03, carried out by teachers who face inertia and opposition (veiled and/or open). The text is based on testimonies collected in an action-research process, through monthly meetings over five years with teachers from public schools (state and municipal) in Rio de Janeiro.

Key-words: Anti-racist education; Geography teaching; Race Relations Education; Daily Routine in Schools; Teacher Protagonism.

\section{DESAFÍOS PARA LA APLICACIÓN DE UNA EDUCACIÓN ANTIRACISTA EN LA ENSEÑANZA DE LA GEOGRAFÍA: CONFLICTOS EN LA PRÁCTICA DIARIA DE LOS DOCENTES}

Resumen: El artículo analiza los desafíos que enfrentan los maestros de Geografía en la vida escolar en la búsqueda de la implementación de la Ley 10.639/03. Basado en una lectura política de las prácticas de los docentes, analiza los conflictos en reacción a las propuestas de contenido, actividades y actitudes de comportamiento en torno a cuestiones raciales. Por lo tanto, la implementación de una educación antirracista y, como parte de ella, una enseñanza de Geografía que desafía los discursos aún hegemónicos basados en racializaciones jerárquicas, aparece como resultado de disputas sobre la interpretación de la Ley 10.639/03, llevada a cabo por maestros que enfrentan inercia y oposición (velado y/o abierto). El texto se basa en testimonios recopilados en un proceso de investigación-acción, a través de reuniones mensuales durante cinco años con maestros de escuelas públicas (estatales y municipales) en Río de Janeiro.

Palabras-clave: Educación antirracista; Enseñanza de geografía; Educación en relaciones raciales; Vida escolar; Protagonismo docente.

\section{DÉFIS POUR LA MISE EN GEUVRE D'UNE ÉDUCATION ANTIRACISTE EN GÉOGRAPHIE PÉDAGOGIQUE: CONFLITS DANS LA PRATIQUE QUOTIDIENNE DES ENSEIGNANTS}

Résumé: L'article discute des défis rencontrés à l'école par les professeurs de géographie dans la recherche de la mise en œuvre de la loi 10.639 / 03. Basée sur une lecture politique des pratiques des enseignants, elle analyse les conflits en réaction aux propositions de contenus, d'activités et d'attitudes comportementales autour des questions raciales. Ainsi, la mise en place d'une éducation antiraciste - et, dans le cadre de celle-ci, d'un enseignement de la géographie qui remet en cause des discours encore hégémoniques fondés sur des racialisations hiérarchiques - apparaît comme le résultat de différends sur l'interprétation de la loi 10.639 / 03, menés par des enseignants confrontés à l'inertie et à l'opposition. (voilée et / ou ouverte). Le texte est basé sur des témoignages recueillis dans un processus de recherche-action, à travers des réunions mensuelles sur cinq ans avec des enseignants du réseau public (étatique et municipal) de Rio de Janeiro. 
Mots-clés: Éducation antiraciste; Enseignement de la géographie; Éducation aux relations raciales; Vie scolaire; Protagonisme de l'Enseignant.

\section{INTRODUÇÃO}

"A primeira semana de aula foi de planejamento no meu colégio, e pelo menos o pessoal da Geografia resolveu fazer coletivo e então fiz desde o sexto, sétimo, oitavo e nono ano. (...) Três professores participaram comigo, sendo que uma professora, numa boa aceitou a implementação dentro dos conteúdos pedagógicos, a implementação da Lei 10639, [mas] um professor de geografia que tem formação aqui nessa faculdade [UERJ-FFP], teve um pouco de resistência. Ele dizia: "mas porque ensinar isso aí, pra que colocar quilombo?". Sabe, questionou o tempo todo, mas no fim ele aceitou, éramos três, duas queriam, ele tinha que entrar." (Professora 4, março de 2010)

O depoimento em epígrafe relata a experiência de uma professora de Geografia que, ao descrever como foi a semana de planejamento pedagógico da escola onde trabalhava, nos evidencia o currículo como um artefato em construção, o que se materializa em embates cotidianos entre diferentes atores, em torno de diversos objetos em disputa. Mais que isso, esse relato possibilita evidenciar que, dentro da Geografia que se ensina existe um pensamento que muitas vezes invisibiliza a história da população negra e sua importância na construção do Brasil. À medida que assumimos que o currículo de Geografia é disputado, também podemos assumir que as formas de ler o mundo também são disputadas no cotidiano escolar.

Desde sua consolidação como disciplina escolar no século XIX a Geografia apresenta, embutido na forma de conteúdos e práticas, um discurso racializado de sociedade e de mundo. Implementada com a função de "servir para fortalecer a ideia do nacionalismo, do expansionismo, do colonialismo, da alienação etc." (CASTROGIOVANNI \& GOULART, 1990, p.112), ao tornar-se o exercício contínuo da doutrinação patriótica (ESCOLAR, 1996), a disciplina historicamente se vinculou aos projetos hegemônicos de nação, consubstanciando seu papel na construção do currículo (mais amplo que um conjunto de conteúdos) como "documento de identidade" (SILVA, 2010).

Se no limiar do século XX a hegemonia das ideologias de superioridade racial branca e das políticas de branqueamento da população constituíam um padrão de 
relações raciais denominado por vários autores de "velho racismo" (CAMINO et. Al., 2001), marcado por formas abertas de manifestação de preconceito, o que inclusive aparecia no tratamento dado ao tema das classificações raciais em livros de Geografia (ver SANTOS, 2018), a mudança de padrão nas relações raciais na segunda metade daquele século leva a novas formas de racialização dos discursos. Mesmo com as inúmeras transformações - principalmente após o movimento de renovação crítica da geografia -, ainda se fazem presentes na geografia que se ensina nas escolas brasileiras as bases de um forte pensamento racializado, pulverizado e camuflado em diversos conteúdos e noções geográficas, que influenciam diretamente o alunado na construção de formas de ler, interpretar e consequentemente se posicionar no mundo (SANTOS, 2007).

Sobre essa dimensão das leituras de mundo, Helena Callai (2005) alerta que,

Fazer a leitura do mundo não é fazer uma leitura apenas do mapa, ou pelo mapa, embora ele seja muito importante. É fazer a leitura do mundo da vida, construído cotidianamente e que expressa tanto as nossas utopias, como os limites que nos são postos, sejam eles do âmbito da natureza, sejam do âmbito da sociedade (culturais, políticos, econômicos). (CALLAI, 2005, p.228)

É no diálogo sobre o papel da Geografia na construção de leituras/visões de mundo que vai incidir no período recente uma busca de releitura crítica antirracista da disciplina. No presente artigo, o interesse recai sobre as disputas que esta releitura engendra. Com efeito, o currículo enquanto instrumento de poder é expressão de correlações de forças sociais, e assim deve ser lido sempre como contendo vetores de dominação e resistências. As hegemonias de forças sociais em projetos de nação, conforme apontamos acima, se expressam em hegemonias curriculares, mas isto deve ser lido sob rasura: há efeitos de poder como relação, sempre em processo de disputas por agentes, sujeitos e personas. Isto implica, como nos aponta Macedo (2006, p. 99), a negação a "uma concepção hierarquizada de poder — seja de cima-para-baixo, seja de baixo-para-cima - que dificulta pensar o currículo para além da prescrição". Tal leitura hierárquica, centrada no Estado, nubla as disputas de currículo, e oculta protagonismos de outros atores sociais que o disputam.

Aqui, propomos pensar estas disputas como fluxo de relações que articulam escalas. Como em Santos (2011a), pensamos as escalas como dimensões espaço- 
temporais de organização das relações sociais, e que no tocante aos processos de construção social de decisões, atinentes ao campo da política, são como "arenas" de disputa. As arenas se articulam a partir dos fluxos da ação social, o que muitas vezes assume padrões de rotinização (e tensões) na forma da institucionalização das estruturas do Estado. O Estado, assim, é visto não como um agente em si, nem como uma construção monolítica, mas como arena de disputas entre as forças sociais - dialogando com a proposta de uma "abordagem estratégico-relacional” de Bob Jessop (2002).

Buscamos, então, compreender como discursos racializados de currículo imanentes ao ensino de Geografia são tensionados e disputados. Houve, no período recente, uma abertura no regime de relações de poder concernentes a esta dimensão curricular, dada pela emergência da luta antirracismo do Movimento Negro Brasileiro desde as duas últimas décadas do século passado (I. A. SANTOS, 2006), que se materializou em legislações e políticas públicas (S.A. SANTOS, 2005) que culminaram na promulgação, em 2003, da Lei Federal n. 10.639. Se na escala nacional podemos apontar o Movimento Negro como ator social que disputa o currículo, buscando uma educação antirracista, como isto se consubstancia no ambiente da escola?

Aqui, tomamos o espaço-tempo da escola através do cotidiano, e o lemos como conjunto de relações que tem poder e disputa como dimensões imanentes. Assim, nossa hipótese é a de que o cotidiano é pleno de práticas que corporificam a afirmação da dimensão racializada hegemônica do/no currículo, mas também de outras práticas que corporificam as resistências e tentativas de transformação antirracista. Nosso olhar se lançará então sobre práticas de professoras e professores que lecionam a disciplina de Geografia, e buscaremos expor uma leitura sobre as relações de disputa em torno da questão racial no ambiente escolar vivenciadas por tais docentes. Tentaremos mostrar como tais docentes, ao propor a releitura dos conteúdos trabalhados na geografia que se ensina, em atividades integradoras e também a crítica dos padrões de relações raciais no cotidiano, causam tensões com saberes e práticas tradicionalmente engendradas nesse ambiente, além de complexificar as leituras sobre como o racismo interfere no ambiente escolar.

Para alcançar tais objetivos, utilizaremos aqui trechos de relatos gravados, transcritos e sistematizados de cinco docentes de Geografia de diversas redes municipais e da rede estadual do Rio de Janeiro, que foram acompanhados em reuniões 
mensais na FFP/UERJ durante quatro anos (2008-2012) pelo projeto de pesquisa "A lei 10.639/03 e o Ensino de Geografia”, vinculado ao Núcleo de Estudos e Pesquisas em Geografia, Relações Raciais e Movimentos Sociais (NEGRAM) ${ }^{3}$. Como será exposto no decorrer do artigo, trata-se de professoras e professores que, através de sua prática, buscavam combater o racismo e as visões estereotipadas e homogeneizantes presentes na geografia (e na escola).

Dessa forma, algumas questões emergem no decorrer do artigo: i) Como se dá a relação entre docentes que tentam introduzir a temática racial a partir de uma perspectiva crítica e antirracista e aqueles que resistem? ii) Como vivem/lidam com alunos, outros professores, outras situações e atores presentes no ambiente escolar? iii) Até que ponto essas disputas configuram arenas de disputa contra o racismo (no ambiente escolar e na sociedade)?

Sem a pretensão de esgotar respostas a esses questionamentos, destacamos o antirracismo, o cotidiano, o currículo e a prática docente enquanto chaves fundamentais para compreender como as relações de poder-saber de base racial se estabelecem no ambiente escolar. Nosso percurso se inicia com a busca de uma compreensão da Lei 10.639 como fruto de disputas, desde a sua formulação até a sua implementação, o que envolve o confronto entre interpretações. Assim, a partir da constituição de um conjunto de ferramentas analíticas, tomamos o agir cotidiano de docentes como objeto empírico a ser analisado, o que fazemos na seção seguinte a partir dos depoimentos colhidos.

\section{1 - A IMPLEMENTAÇÃO DA LEI 10.639 NA PRÁTICA DOCENTE: O CONFLITO COMO CHAVE DE LEITURA POSSÍVEL PARA COMPREENDER O COTIDIANO}

Desde a década de 1930 o Movimento Negro Brasileiro vinha buscando, como uma de suas reivindicações, que políticas públicas de educação contemplassem um equilíbrio nas representações dos grupos que compõem a nação. Nas décadas de 1980 e 1990, como nos mostra Santos (2005), em alguns municípios e estados do país começaram a surgir leis neste sentido regulando currículos, através da inserção

\footnotetext{
${ }^{3}$ O NEGRAM está vinculado ao Departamento de Geografia da Faculdade de Formação de Professores da Universidade do Estado do Rio de Janeiro (FFP-UERJ) e dedica-se ao fortalecimento da relação entre a produção de conhecimento e lutas sociais, no campo da Geografia.
} 
obrigatória de conteúdos e também da revisão de conteúdos que se acreditava contribuírem para o racismo.

O jurista Hédio Silva Jr. (1998, apud SANTOS, 2005) fez um levantamento de tais leis, e mostra que elas traziam redações com conteúdos bastante distintos, como:

- "É dever do Estado preservar e garantir a integridade, respeitabilidade e permanência dos valores da religião afro-brasileira e especialmente (...) promover a adequação dos programas de ensino das disciplinas de Geografia, História, Comunicação e Expressão, Estudos Sociais e Educação Artística à realidade histórica afro-brasileira (...)" (Constituição do Estado da Bahia, promulgada em 05/10/1989);

- “inclusão do conteúdo programático sobre a história da África e cultura afro-brasileira no currículo das escolas públicas municipais" (Lei Orgânica do Município de Belo Horizonte, promulgada em 21/03/1990);

- "Fica incluído, nas escolas de $1^{\circ}$ e $2^{\circ}$ graus da rede municipal de ensino, na disciplina de História, o ensino relativo ao estudo da Raça Negra na formação sociocultural brasileira" (Lei Municipal 6.689, de 05/09/1991, de Porto Alegre);

- "As escolas municipais de $1^{\mathrm{o}}$ e $2^{\mathrm{o}}$ graus deverão incluir em seus currículos 'estudos contra a discriminação racial"” (Lei Municipal 11.973, de 04/01/1996, de São Paulo).

$\mathrm{O}$ autor mostra exemplos de leis de teor semelhante em municípios como Belém e Aracaju, mas para não nos alongarmos, trouxemos estes quatro exemplos, suficientes para levantar a questão da diversidade de propostas materializadas em leis, fruto das lutas históricas daquele movimento social. Elas nos indicam uma pluralidade de sentidos, objetivos, temas e formas de implementação, incidindo em uma disciplina ou em várias, por exemplo. A Lei Federal no 10.639, promulgada em 09/01/2003, nacionaliza tais propostas alterando a Lei de Diretrizes e Bases da Educação Nacional, e se coloca como uma tentativa de sintetizar esta pluralidade de propostas materializadas anteriormente em leis municipais e estaduais. Tal síntese se materializa na seguinte redação:

"Art. 26-A. Nos estabelecimentos de ensino fundamental e médio, oficiais e particulares, torna-se obrigatório o ensino sobre História e Cultura AfroBrasileira.

$\S 1$ o O conteúdo programático a que se refere o caput deste artigo incluirá o estudo da História da África e dos Africanos, a luta dos negros no Brasil, a cultura negra brasileira e o negro na formação da sociedade nacional, 
resgatando a contribuição do povo negro nas áreas social, econômica e política pertinentes à História do Brasil.

$\S 20$ Os conteúdos referentes à História e Cultura Afro-Brasileira serão ministrados no âmbito de todo o currículo escolar, em especial nas áreas de Educação Artística e de Literatura e História Brasileiras.

(...)

"Art. 79-B. O calendário escolar incluirá o dia 20 de novembro como 'Dia Nacional da Consciência Negra'." (BRASIL, 2003) (grifo nosso)

Trazer o texto da Lei 10.639/03 como síntese (possível dentro dos processos políticos de disputa, discussão e tomada de decisão) das lutas históricas do Movimento Negro e que tem como antecedentes outras legislações municipais e estaduais nos ajuda a refletir sobre o seu processo de implementação. Com efeito, este também será marcado pela diversidade de sentidos e significados atribuídos a ela, que caracterizam disputas de interpretações. Como ocorre em toda lei, a implementação é sempre debatida e disputada pelos aplicadores. Sendo uma lei no campo da Educação, ela terá como aplicadores tanto os sujeitos envolvidos com a construção (formulação, execução, avaliação) de políticas públicas como aqueles que são os sujeitos centrais do processo educativo, que são os atores da comunidade escolar. Esta pluralidade de atores e de arenas, somada à pluralidade da abrangência e escopo da Lei, resulta em complexos processos (e, como parte deles, também inércias) na aplicação da Lei 10.639/03. O cotidiano escolar se apresenta, assim, como uma (ou, um conjunto articulado de) arena(s) privilegiada(s) para a observação desta circulação e disputa de sentidos em torno da Lei e sua implementação.

Uma das mais frequentes disputas é sobre a abrangência disciplinar da Lei: mesmo ela contendo em seu texto a afirmação de que se aplica em "todo o currículo escolar", o fato de ter também o "em especial nas áreas de Educação Artística e de Literatura e História Brasileiras" faz com que grande parte da comunidade envolvida a interprete como sendo restrita a estas disciplinas nominalmente mencionadas. A Geografia aparece neste cenário como uma disciplina que, não sendo nominalmente mencionada, terá sujeitos afirmando e defendendo que a Lei 10.639 não incide sobre ela. De outro lado, temas trazidos na redação da Lei, como "História da África" e "a cultura negra brasileira e o negro na formação da sociedade nacional" já integram (ou, ao menos, dialogam fortemente com) o escopo da disciplina. Instauram-se assim 
disputas em torno do tratamento ou não dos conteúdos decorrentes da Lei no ensino desta disciplina.

Tais formas de interpretar o escopo da Lei para sua implementação, mais restritivas ou mais abrangentes, vão se constituir em disputas, em todas as arenas em que decisões estão em jogo. Uma delas é o cotidiano escolar. No âmbito do projeto de pesquisa “A Lei 10.639/03 e o ensino de Geografia", acompanhamos (e, fortalecemos a prática de) 5 docentes de escolas públicas localizadas em diversos municípios do Rio de Janeiro, de 2008 a 2012. Através de reuniões mensais, depoimentos construíam um ambiente de diálogo sobre o trabalho executado (e planejado) em que, além de conteúdos e materiais, eram compartilhadas e debatidas as vivências, êxitos, dificuldades de cada qual em seus ambientes escolares e redes. Esta abordagem, baseada numa metodologia de pesquisa-ação (relatada por Santos, 2012), nos permite aqui problematizar o impacto das releituras dos conteúdos trabalhados na Geografia, nos saberes e práticas tradicionalmente engendradas no ambiente escolar, a partir da análise de como se dá construção do currículo no cotidiano de algumas professoras e professores que tinham em sua atuação, uma prática antirracista. Essa opção nos permitiu construir uma análise interessante: a) para o campo do Ensino, uma vez que confere relevância às relações presentes no ambiente escolar e ao professor - através da sua prática cotidiana - um protagonismo na construção do currículo; e b) para a Geografia, uma vez que ajuda a problematizar como se dá a construção e introdução de conteúdos programáticos e práticas pedagógicas que visam, através de uma leitura geográfica, romper com um pensamento político-ideológico ainda hegemônico.

Assumimos aqui, portanto, o conflito como categoria de análise central para a compreensão dos processos de transformação (versus inércias, permanências) que deveriam configurar a implementação da Lei 10.639, como vetor de construção de uma educação antirracista - e o cotidiano escolar como foco privilegiado de nossa análise. Esta escolha pelo conflito, em detrimento de outras chaves de leituras possíveis para os mesmos cotidianos analisados, para nós ganha em importância pela necessidade de compreender sobretudo as inércias e permanências no currículo praticado e no ensino de Geografia em relação à Lei 10.639. É comum se apontar que a implementação "não avançou", "não chegou", e muitos discursos (inclusive, coletados em nossa pesquisa e 
nas dezenas de oficinas "Racismo e Educação" realizadas em escolas pela equipe ${ }^{4}$ ) de professores/as indicando como razão a falta de (in)formação acerca da educação das relações raciais por parte do corpo docente. Acreditamos que, para mais além de "falta" de (in)formação - questão que não negamos e nem consideramos de menor relevância -, existem também comportamentos reativos, de resistência à própria Lei e aos discursos antirracistas - comportamentos estes que configuram forças inerciais que contribuem para a não implementação da Lei. Assim, para buscar esta compreensão, a partir da centralidade do conflito, abrimos mão de ler outras dimensões constitutivas dos mesmos cotidianos escolares que analisamos, como $\mathrm{p}$ ex, as tessituras de conhecimento construídas em tentativas logradoras de sucesso - que apresentamos em outros trabalhos como os de Araujo (2010), Monteiro et alii (2011), Rocha (2011), Santos, C. A. C. dos. (2013), Correa (2013), Diniz (2015), Santos, R.C. (2017).

Ao tomar os conflitos vivenciados pelos docentes como objeto de análise, emerge para nós a dimensão do currículo praticado como fruto de relações de poder no cotidiano - este, visto como espaço-tempo complexo, caracterizado em cada ambiente escolar por padrões singulares de interações e relações de poder-saber, cuja organização e rotinização expressa as relações de dominação constituídas no todo social visando atender a interesses de grupos hegemônicos ${ }^{5}$, mas que também é palco de atuação de atores insurgentes. Ao optarmos por esse caminho, objetivamos evidenciar o cotidiano como palco de uma série de interações imbricadas, que servem: i) para assegurar a própria re-produção desse espaço-tempo; ii) para garantir o funcionamento de acordo com o que a sociedade (com seus embates entre forças sociais, dominações e hegemonias) exige dele; mas também iii) para a busca da transformação, de práticas insurgentes, da instauração do novo e da busca pelos inéditos viáveis. Cabe ressaltar, não se tem a intenção aqui de falar que o cotidiano não possui a confluência de diferentes experiências, mas sim, que além dessas, apresenta outras relações, interações, trajetórias, que permitem evidenciar a existência de um complexo padrão de relações, que se organizam na forma de "fluxos rotinizados" (GIDDENS, 2003).

\footnotetext{
${ }^{4}$ Conforme relatado em SANTOS et. Al. (2019), entre 2011 e 2014 a equipe da pesquisa realizou 41 oficinas, 35 das quais em escolas.

${ }^{5}$ Afinal, como nos mostra Foucault, a escola é (não apenas, mas também) uma das tecnologias de disciplinamento de corpos, uma tecnologia de poder.
} 
A compreensão das inércias curriculares que dificultam a implementação de uma educação antirracista passa (também, mas, como queremos aqui mostrar, não apenas) pelas formas de ("tentativas" de controle da) organização do/no cotidiano. Aqui, dialogando com Goffman (1985), o pensamos como um "cenário", com contextos articulados em campos, tipos e espaços de interações, que consequentemente refuncionalizam a própria estrutura da escola. A busca da rotinização das interações (pela burocratização) dá lugar a essa articulação através de dimensões técnicas e estruturais (GOFFMAN, 1985) cristalizando uma organização espaço-temporal de funções, de papéis, de atos que são organizados e mobilizados para acomodar tensões ou possíveis tensões dentro do ambiente escolar. Assim, se legitima politicamente (GOFFMAN, 1985) determinadas ações, ao mesmo tempo que se impede que novas práticas sejam engendradas. Com isso, este ambiente não é apenas o lugar do novo, do diferente, ou o palco do exercício e da liberdade pedagógica (como é visto em diversas leituras sobre o cotidiano escolar), sendo ao mesmo tempo a esfera de relações em que se normatiza, controla e barra um conjunto de saberes e práticas passiveis ou não de serem implementadas.

Ambas as dimensões - controle/vedação/inércia e liberdade/criação/tessituras estão presentes no cotidiano, e aqui em nossa leitura escolhemos privilegiar a compreensão dos conflitos como mecanismo inercial às transformações. Por isso, ao ler a ação de docentes disputando o currículo no cotidiano, ao invés de utilizarmos a categoria "praticantes", como nos influencia Certeau (1994), falamos aqui de "interlocutores". Assim, nos aproximamos da ideia de "antagonistas", mas também a descartamos por não expressar as posições - não fixas - que estes assumem nos imbricamentos de jogos, disputas e relações de poder de que participam. Nestes, as próprias categorias posicionais "a favor" e "contra", que aqui optamos por utilizar, nós também mostramos que não dão conta - arenas e disputas se entrecruzam, complexificando posições e comportamentos, conforme veremos na próxima seção.

\section{2 - A PRÁTICA DOCENTE ANTIRRACISTA E AS TENSÕES NAS RELAÇÕES DO/NO COTIDIANO ESCOLAR}


A fim de investigar as tensões envolvidas na disputa do/pelo currículo praticado (ALVES, 2001) no tocante à aplicação da Lei 10.639 por docentes da disciplina Geografia, tomamos como fonte as gravações e transcrições de depoimentos constantes dos relatórios do projeto de pesquisa “A Lei 10.639 e o Ensino de Geografia”, prestados por cinco docentes nas 38 reuniões realizadas entre 2008 e 2012. O referido acompanhamento, já explicado acima, ao gravar e transcrever as reuniões, gerou um arquivo no formato Microsoft Word (formatado com fonte Times New Roman, tamanho 12, espaço simples) de 1.413 páginas. Após o tratamento da informação, optamos aqui por selecionar alguns depoimentos, apresentar algumas questões sobre os conflitos, para posteriormente problematizar os impactos da resistência ao combate do racismo na prática das professoras e professores acompanhados.

Além dos embates acerca da temática racial e das interpretações sobre a Lei 10.639, é importante considerar também alguns elementos concernentes à própria constituição destes sujeitos das disputas que analisamos, bem como as próprias arenas em que exerciam tais disputas. Preservando as identidades das professoras e professores acompanhadas(os) e também das escolas em que eles atuavam, a Tabela 1 "Relação dos professores e professoras acompanhados pela rede pública de ensino e localidade em que a escola está inserida" nos mostra uma diversidade de (i) pertencimentos de raça e gênero dos sujeitos, (ii) redes de educação à qual cada escola está vinculada (o que significa diferentes diretrizes políticas de gestão regulando as práticas das/os docentes) e (iii) inserções espaciais das escolas (em áreas centrais e periféricas da Cidade do Rio de Janeiro, de dentro e de fora da Metrópole, em áreas urbanas e rurais - que condicionam diferentes públicos discentes e comunidades extra-escolares, implicando em profundas distinções nos padrões de sociabilidade). Tais fatores, entre outros, incidem sobre o cotidiano escolar e os padrões de disputa que nele se instauram.

Tabela 1: Relação dos professores e professoras acompanhados pela rede pública de ensino e localidade em que a escola está inserida

Professor(a)

Professor 1 (pardo*)

\section{Rede Pública de Ensino/Localidade da Escola}

Rede Municipal do Rio de Janeiro/Escola localizada no bairro de Bangu (Zona Oeste da cidade do Rio de Janeiro)

Rede Estadual do Rio de Janeiro/Escola localizada no bairro de Copacabana (Zona Sul da cidade do Rio de Janeiro) 
Professor 2 Rede Municipal do Rio de Janeiro/ Escola no bairro de Bonsucesso (Zona Norte da (branco*) cidade do Rio de Janeiro)

Rede Estadual do Rio de Janeiro/Escola localizada em Venda das Pedras/Itaboraí (Município do Leste Metropolitano do Estado do Rio de Janeiro)

\begin{tabular}{cl}
$\begin{array}{c}\text { Professora } 3 \\
\text { (preta*) }\end{array}$ & $\begin{array}{l}\text { Rede Municipal de São Pedro da Aldeia/Escola localizada na zona Rural de São } \\
\text { Pedro da Aldeia (Região dos Lagos do Estado do Rio de Janeiro) } \\
\text { Rede Estadual do Rio de Janeiro/Escolas localizadas nos municípios de Tanguá e } \\
\text { Itaboraí (municípios do Leste Metropolitano do Estado do Rio de Janeiro) }\end{array}$ \\
\hline $\begin{array}{c}\text { Professora 4 } \\
\text { (preta*) }\end{array}$ & $\begin{array}{l}\text { Rede Estadual do Rio de Janeiro/ Escola localizada no centro de Niterói (Município } \\
\text { do Leste Metropolitano do Estado do Rio de Janeiro) }\end{array}$ \\
\hline $\begin{array}{c}\text { Professora 5 } \\
\text { (preta*) }\end{array}$ & $\begin{array}{l}\text { Rede Municipal do Rio de Janeiro/Escola localizada no bairro de Bangu (Zona } \\
\text { Oeste da cidade do Rio de Janeiro) e escola localizada no bairro de Água Santa } \\
\text { (Zona Norte da cidade do Rio de Janeiro) }\end{array}$
\end{tabular}

Fonte: NEGRAM. Projeto de pesquisa "A Lei 10.639 e o ensino de Geografia", 2013. *Classificação racial feita pelos autores (heteroclassificação).

Além da diversidade de realidades em que atuam, é interessante também destacar as diferenças nos processos de formação (tanto política quanto acadêmica) dessas(es) profissionais ${ }^{6}$. Entre as professoras e professores, existem graduadas(os) e pós-graduadas(os) formadas(os) na Faculdade de Formação de Professores Universidade do Estado do Rio de Janeiro (FFP-UERJ), na Universidade Federal Fluminense (UFF), na Pontifícia Universidade Católica do Rio de Janeiro (PUC-RIO), na Faculdade de Filosofia de Campo Grande (FFCG) e na Universidade Federal do Estado do Rio de Janeiro (UNIRIO), o que apresenta uma diversidade de perspectivas sobre geografia e sobre educação.

Para além da graduação (formação inicial), essas professoras e professores também possuíam distintas formações políticas, das quais destacamos suas inserções em movimentos sociais e outras entidades. É o caso, p ex, do Professor 1, que durante a sua formação chegou a atuar junto ao movimento de pré-vestibular comunitário, e na Associação dos Geógrafos Brasileiros (AGB) seção local Rio de Janeiro. Outra professora que também militava na AGB, mas na seção local Niterói, era a professora 3, que além dessa instituição, tinha no Partido dos Trabalhadores (PT) um dos campos de atuação/formação.

Como poderemos ver na apresentação dos conflitos, é importante salientar que as professoras 3, 4 e 5, enquanto professoras negras, também tinham nestes dados

\footnotetext{
${ }^{6}$ Dados retirados do relatório do projeto de pesquisa "A lei 10.639/03 e o Ensino de Geografia", da plataforma Lattes e da dissertação "A Formação contínua de professores de Geografia para implementação da Lei Federal n ${ }^{\circ}$ 10.639/03: A partir de um projeto de pesquisa-ação" defendida por Flávio Guimarães Diniz (2014).
} 
(pertencimentos de raça e gênero), um conjunto de enfrentamentos que mobilizavam não só o tratamento sobre o campo disciplinar, mas o próprio tratamento que elas recebiam, enquanto mulheres, e enquanto negras.

Para melhor visualizar, esses conflitos foram sistematizados em duas categorias de análise por nós propostas: os embates e os dilemas. O primeiro está ligado a uma variedade de conflitos perceptíveis através de ações diretas e/ou indiretas, engendradas por outros atores do cotidiano escolar. São ações que vão desde mudanças de comportamento/tratamento, até o boicote deliberado às atividades realizadas por esses professores. Ou seja, chamamos aqui de "embates" as situações de impasse ou disputa que se caracterizam por ter "interlocutores" se posicionando como oposição ao sujeito conforme já apontado, preferimos o termo "interlocutores", ao invés de outro como p ex "antagonistas", por conta da necessidade de relativização da posição assumida pelo sujeito. Já os "dilemas" não têm a dimensão explícita do embate com outros atores do cotidiano, mas se configuram em relações de disputa onde nem sempre é possível identificar um interlocutor, ocasiões que colocam os professores em situações de difícil escolha. Elas podem envolver desde problemas estruturais, como a falta materiais para fazer uma atividade, até relações que inúmeras vezes extrapolam o ambiente escolar como a violência em torno do colégio, a relação com a secretaria de educação etc. Apesar das situações que categorizamos como "dilemas" não explicitarem uma relação de oposição, as mantivemos como modalidades de "conflitos" por serem também entraves impostos à ação dos docentes acompanhados, na sua busca pela implementação da Lei 10.639.

Ao longo das 41 reuniões que ocorreram nesses cinco anos, as três professoras e os dois professores acompanhados relataram um total de 84 conflitos. Destaca-se ainda, que destes, 54 giraram em torno dos embates, se conformando na maior parte dos conflitos enfrentados pelas(os) professoras(es), e 30 foram considerados dilemas.

Como o objetivo principal dos relatos não era apresentar os conflitos presentes no cotidiano, cabe ressaltar que as(os) professoras(es), ao reconstruírem a sua prática no cotidiano escolar, privilegiavam algumas formas de enfrentamentos em detrimento de outras - alguns se concentravam apenas nos conteúdos planejados e trabalhados. Como resultado disso, conseguimos obter de forma "espontânea" um amplo banco de dados sobre os entraves para o tratamento da questão racial em várias esferas do cotidiano 
escolar. Nesse sentido, como é possível ver no gráfico a seguir, existe uma maior incidência de algumas/alguns no relato de embates, e de outras(os), no relato de dilemas - ao passo que no caso dos professores que tem aqui poucos conflitos (embates ou dilemas) relatados, isso não significa necessariamente que não os vivenciassem, mas sim, que não adotavam tal dimensão de suas vivências como prioridade ao fazer os seus relatos.

Gráfico 1 - Relação entre Embates e Dilemas por Professor(a)

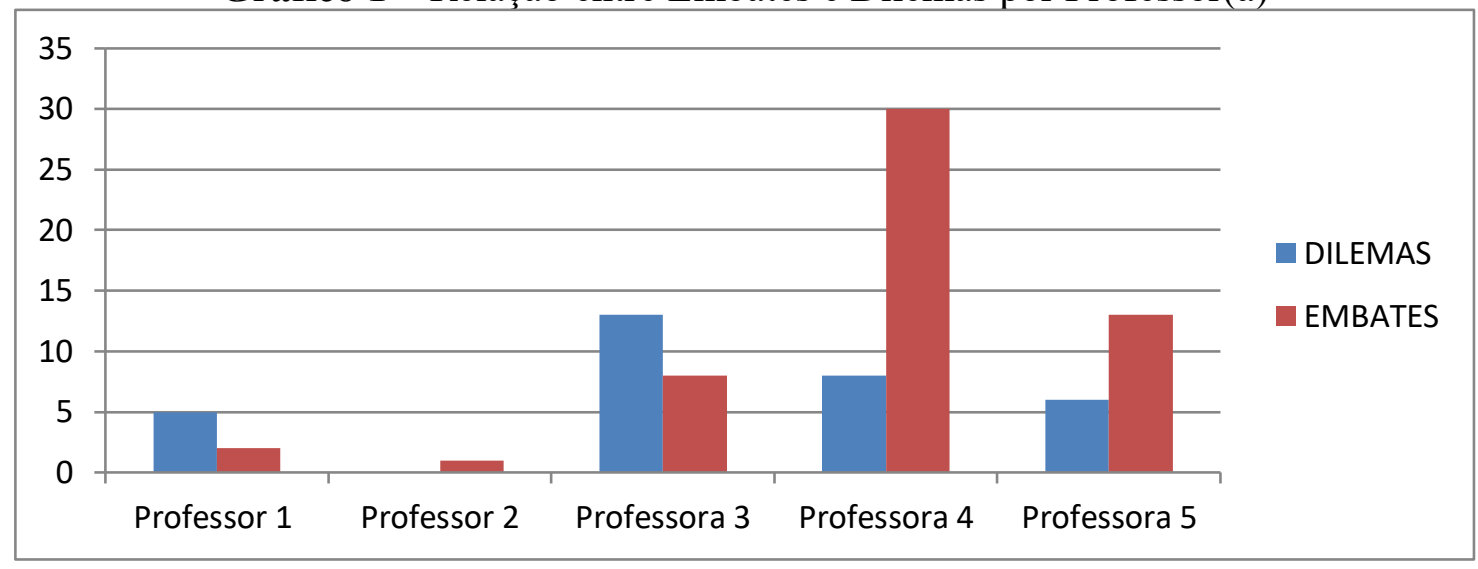

Fonte: NEGRAM. Projeto de pesquisa “A Lei 10.639 e o ensino de Geografia”, 2013.

Cabe salientar também, que além das diferentes formas de relato, devido a precarização do sistema educacional, e do regime de trabalho imposto aos profissionais da educação, alguns dessas(es) professoras(es) não conseguiam, dentro de sua prática cotidiana, perceber algumas relações de poder-saber existentes no cotidiano escolar. É o caso do professor 2, que frente aos dilemas e embates dos outros professores, relata que:

\footnotetext{
Para mim fica mais difícil de observar essas coisas porque eu trabalho em uma "cacetada" de escolas ficando cada vez menos tempo então eu não tenho muito contato com os professores, diretor e muito menos com coordenador. [...]

Acaba que a gente não se dedica muito a nenhuma das instituições que a gente trabalha, mas o que dá para perceber de certa forma que o tipo de relacionamento, esse tipo de debate entre alunos dá para perceber porque $o$ maior tempo a gente está em sala de aula, $[\ldots]$ e é onde a gente tenta dar uma equilibrada na relação (Professor 2, setembro de 2009)
}

Ao fazer esse relato, o professor 2 apresenta uma das faces desse regime de trabalho, que é a impossibilidade de diversos professores vivenciarem seus cotidianos escolares de uma maneira densa. Ou seja, o fato de lecionar em diversos lugares faz 
com que as suas relações cotidianas sejam abaladas, inclusive para perceber essas "regulações" presentes no cotidiano escolar. Cabe realçar que, além desse regime restringir a interação dele com outros(as) docentes, ele também impede uma maior interação com os(as) discentes. Isso faz com que processo educacional seja prejudicado, restando ao professor o esforço de articular as discussões com os conteúdos, transformando os conteúdos em uma saída para tensionar o racismo no cotidiano escolar. Essa "baixa interação", somada às diferentes formas de relato, faz com que esse professor apresente em seus relatos uma situação de baixa conflitividade quando comparado com os conflitos relatados pelos seus pares, em especial a professora 4 única professora que trabalha somente em uma escola.

Através desses relatos, também conseguimos experiências que evidenciam o conflito com diferentes atores, em diferentes espaços e em torno de diferentes objetos. Para melhor organizar esses dados, os mesmos foram sistematizados de forma a visibilizar os interlocutores no caso dos embates, assim como os motivos para os conflitos acontecerem, no caso dos dilemas.

Tratamos enquanto interlocutores dos embates, os diferentes atores com quem os professores mantiveram uma relação conflituosa e/ou de alianças no cotidiano escolar. Como forma de analisar a recorrência de um determinado tipo de interlocutor, estes foram divididos da seguinte forma: Estudantes (6), Docentes (21), Coordenação/Direção da escola (28), Comunidade Escolar (2) Secretaria de Educação (5), Outros atores (2). Dessa forma, podemos visibilizar a recorrência das relações de alianças e/ou disputas construídas no cotidiano desses professores. Cabe salientar que devido à complexidade dos conflitos relatados, em diversos momentos as(os) professoras(es) apresentavam a interação com mais de um grupo exposto acima, exercendo (dependendo do contexto) papeis de alianças e/ou disputas. Apesar de ser uma amostra que revela um "universo" específico de análise, no conjunto de relatos, identificamos que a maior parte dos interlocutores eram respectivamente a Coordenação/Direção da escola e as(os) professoras(es).

O panorama apresentado após analisar a recorrência de interlocutores, fez com que algumas indagações fossem apresentadas: o que faz com que existam tantos embates entre os professores acompanhados e a direção e outros professores? Quais são 
os catalizadores dessas relações de conflito? Em torno de que giram essas disputas? Quais são os “objetos” mais disputados nessas relações cotidianas?

Com o objetivo de compreender melhor essas relações de embate, sem que com isso se perca algumas particularidades, agrupamos os objetos em disputa em torno dos eixos: Evento interdisciplinar (19), Currículo praticado (12), Disputa políticopedagógica (17), Tratamento/Comportamento sobre a temática racial (9) e Outros (5). Apesar de compreender que algumas dessas disputas dialogam entre si, como é o caso dos eventos interdisciplinares e a questão do currículo praticado, e as disputas políticas e o comportamento/tratamento sobre a temática racial no ambiente escolar, optamos por apresentá-las de maneira separada para ressaltar a dimensão do objeto em disputa. Vemos que apesar de existir uma concentração dos embates no tocante aos tipos de interlocutores, não existe uma concentração no que tange aos objetos em disputa. Assim, uma análise qualitativa destes embates é que mais nos municia para pensar os desafios da implementação da Lei 10.639 pela ação docente no cotidiano escolar.

Antes de tomarmos alguns exemplos sobre esses desafios, cabe ressaltar que a definição das categorias de análise aqui propostas para a compreensão dos conflitos vivenciados por docentes de Geografia em sua aplicação da Lei 10.639 no cotidiano escolar derivam da compreensão do que em Santos (2011b) foi sistematizado como “fatores reguladores' da prática dos professores, conjunto de elementos com os quais estes se defrontavam e que de alguma maneira exerciam interferência decisiva em suas possibilidades de ação. Assim, das análises brotavam como fatores reguladores cruciais (i) os livros didáticos, (ii) as relações com outros professores de Geografia (pelas negociações dos programas, conteúdos e enfoques praticados), (iii) relações com professores de outras disciplinas ${ }^{7}$, (iv) as relações com coordenação pedagógica e demais atores da gestão escolar (sobretudo nos chamados "projetos" temáticos interdisciplinares e de organização de eventos), e (v) questões como a violência na sociabilidade dos alunos, influência de estruturas criminosas e de narcotráfico, condições de recursos materiais e humanos da escola (ausência ou insuficiência de

\footnotetext{
7 “(...) mesmo que não haja diálogo entre professores, conteúdos das disciplinas dialogam e, quando um começa a trabalhar as demandas da Lei 10.639, muito facilmente entra em colisão com leituras eurocêntricas de outros professores. Esta colisão disciplinar muito facilmente transborda para relações pessoais e políticas, pois questionamentos dos alunos neste sentido são trazidos para as relações entre os professores." (Santos, 2011b, p. 9)
} 
inspetores potencializando problemas disciplinares e organização de horários), perfil da turma, entre outros.

Como tais reguladores apareciam nos depoimentos? Um exemplo, é a negociação curricular junto a outros docentes de Geografia que aparece no depoimento colocado na epígrafe que abre este artigo. No relato, a professora mostra como a equipe da disciplina, no início do ano letivo, se reuniu para realizar um planejamento conjunto e ela, inspirada e municiada pelos temas e materiais discutidos no processo de pesquisa no ano anterior, tomou tal reunião como uma arena de disputa curricular, na qual ela poderia disputar a execução de uma prática de ensino antirracista para além da aula dela, influenciando nas aulas dos outros dois docentes que compunham a equipe. Ali, encontra a resistência de um colega, realiza o debate, e consegue conquistar o apoio da outra colega, considerando-se então "vencedora" da disputa curricular do episódio. Isto, evidentemente, não garante que o combinado tenha efetivamente sido colocado em prática pelo colega contrário, que pode ter não adotado tais conteúdos em suas aulas tal confirmação não foi posteriormente abordada nos relatos nas reuniões de pesquisa naquele ano.

Para nossa análise, aqui, importa compreender tal momento de planejamento como a instauração de uma "arena" de disputa curricular constituída no cotidiano escolar, que comporta um embate - e, distintas assunções/tomadas de posições pelos agentes envolvidos, tanto de oposição a uma determinada estratégia de implementação da Lei 10.639 e de construção de um ensino de Geografia antirracista, quanto de aliança, postura da outra docente que permitiu que a proposta fosse vencedora. Nesta situação, temos (i) um embate, situação configurada pela existência de (ii) agentes em disputa (a professora proponente e os outros dois que integravam a equipe de Geografia), (iii) um objeto (a inserção da temática racial e sua forma de tratamento) e (iv) um sistema de posições (que aqui optamos por simplificar em "a favor"/aliadx e "contra"/opositor ou opositora) que deriva das formas como cada um dos agentes se relaciona com o objeto da questão em tela (a temática racial). Entretanto, identificamos nos depoimentos colhidos na pesquisa também situações em que tais ferramentas de análise não dariam conta da complexidade envolvida. Vejamos o seguinte depoimento, que é longo, mas proporcionalmente elucidativo: 
"Bem, nesse momento na escola acabamos o terceiro bimestre, houve avaliação, houve um conselho e... Aproveitamos esse momento de encontro no conselho e, dando continuidade, a ideia de socializar é... Democraticamente dentro da escola, essa discussão da Lei 10.639 e também a execução da lei... Aproveitando essa oportunidade para haver uma discussão. Enfim... A direção sempre está aberta a isso, o espaço está garantido. Ficou fechado com os professores que já haviam trabalhado em anos anteriores, estamos nos reunindo outra vez pra montar a linha que vai ser esse ano, porque todo ano a gente homenageia alguém, trabalha com alguns personagens, seleciona alguns filmes, então já programamos mais ou menos o que nós vamos fazer em novembro. E, enfim, mas a grande questão que está me preocupando é o embate político interno, porque mais uma vez, uma professora do grupo que trabalha comigo há muito tempo, acha que não deve, acha a gente não deve fazer aliança com a direção. Tipo assim, se a direção fechou um dia com a gente e está oferecendo todos os tipos de recurso, mas ela acha que isso é uma aliança com a direção, com a política da direção, enfim... Aí é aquele embate... Mas que me preocupa muito, porque a professora que sente incomodada com essa aliança com a direção, ela sofre por causa disso literalmente, ao ponto dela falar assim "eu até adoeci", porque... Ela falou assim pra mim, "eu não tô te reconhecendo". Cadê a nossa fidelidade? Cadê a nossa postura política? Cadê a nossa ética? Entendeu? Me cobrando mesmo. Aí eu fico assim, "gente..." Eu digo, eu não acho que eu estou perdendo a minha postura política, a minha ética, porque eu quero socializar isso com todos, entendeu? É um conhecimento que eu não quero que fique restrito a nós, um grupo fechado, eu quero que todos participem independente do cunho político, religioso, se não vai virar um "fundamentalismo", né? Então, mas ela continua cada vez mais fechada, e eu não sei como vai dar isso, porque ela condiciona de estar trabalhando, e ela é uma pessoa que tem um trabalho maravilhoso - que é a professora de Literatura e Português dentro da escola, então ela tem espaço pra fazer um belo trabalho dentro da escola. Ela sempre contribuiu muito, mas condicionou, só vai participar se a direção estiver fora, se a direção não entrar. Inclusive, incomodou à beça a ela quando a direção resolveu... Porque aí eu fico no meio da luta, porque as duas disputam o mesmo o espaço dentro da escola, e... Então, eu acho que a direção vai pagar esse curso, até para afrontá-la, entendeu? Porque ela [a direção] não queria pagar mesmo um [outro] curso para todos os professores que desejarem, trinta reais à princípio, porque o preço vai aumentando. E... Enfim, a direção fica todo o tempo falando muito dos professores, do meu trabalho dentro da escola, aí que ela [a professora de Literatura] se incomoda mesmo, porque aí ela acha que isso é esvaziar o nosso trabalho mesmo, que isso é... Enfim, ela tem uma posição política que até o momento é correta, mas que não deve destruir o nosso trabalho. E se ela continuar a ficar dessa maneira, ela vai acabar se afastando de todo mundo, ela está adoecendo por causa dessa questão, ela falou assim: "Puxa, a gente já trabalha junto tantos anos, nunca precisamos de direção alienada, por que agora você vai compactuar com essa gente?". Então a questão política é séria dentro do grupo." (Professora 4, outubro de 2008)

Neste episódio, a professora depoente da pesquisa estava propondo a realização de uma Semana Afro na escola como estratégia de incorporação do Dia da Consciência

Negra ao calendário escolar. A direção concordou e ofereceu apoio, mas outra 
professora, parceira antiga da depoente (elas e mais outras duas já haviam trabalhado juntas em outra escola anteriormente, e tinham um grupo que já ali realizava atividades de pesquisa, ensino e disputava politicamente a direção), passou a se posicionar contra a atividade, caso fosse realizada aceitando o apoio da direção. Ressalte-se, segundo a depoente, a professora que então se opôs, sempre foi aliada na construção de uma educação antirracista, tanto nesta quanto na escola anterior em que trabalharam juntas, mas neste momento, se posicionou contra. Temos aqui uma situação em que o sistema de posições se complexifica, ao misturar dois campos de disputa: de um lado, a disputa pela construção de uma educação antirracista e implementação da Lei 10.639, e de outro, a disputa pela condução política da escola. Cada um destes campos tem seu próprio sistema de posições (“a favor" e "contra"), mas as tomadas de posições na disputa pela condução política da escola interferem aí nas posições assumidas em torno do agir antirracista. Com efeito, o arranjo das agentes envolvidas na disputa política da escola faz com que uma professora que assumia a luta antirracismo em seu fazer preferisse abrir mão desta posição para se manter em oposição à direção: o combate ao racismo é colocado, na perspectiva desta docente, como algo secundarizado frente às suas disputas políticas com a direção - o que levou neste episódio ao afastamento da depoente da pesquisa em relação ao seu tradicional grupo político na escola. O cotidiano escolar aparece, aqui, como um complexo campo de disputas, em que as posições são cambiadas de acordo com os diversos interesses em jogo - e, a constituição de um agir antirracista, é apenas um, e que sofre influências de outras questões que extrapolam crenças, visões de mundo e posicionamentos dos agentes em relação à temática racial.

Assim, um embate em torno do debate sobre a temática racial pode ter seu jogo de posições diretamente influenciado e modificado por conta de fatores alheios às visões que os agentes tem sobre ele, relativizando assim compromissos, vínculos $\mathrm{e}$ engajamentos. A personalização dos vínculos, e a estigmatização de sujeitos, emerge como um dos padrões de relações observados. Vejamos o seguinte depoimento:

[...] eu passei a ser logo a chata, fiquei falada por professores, questionando quem era eu para falar sobre a postura, o comportamento de alguns professores. [...] discordo da maneira que questionam a postura de alunas, que é errada em muitos momentos, mas não é por isso que na sala eu vou chamar uma aluna de piranha, não é por isso que eu vou chamar um aluno de pobre, preto e favelado. 
Não é por isso que eu vou dizer para você, que sua mãe não faz nada é uma desocupada, e você também é desocupado.

E eu tentava colocar para a direção que essas questões tinham cunho racial sim, que eles acham que não, que essa clientela ouve isso porque merece ouvir. E aí esse primeiro grupo teve essa discussão, e eu me coloquei no que eu tinha dito, de fazer uma critica à postura da direção, porque eu acho que a direção tinha que fazer isso, só o que aconteceu, eu virei a antipática, já não era bem vista, passei a ser mais odiada ainda e o que mais me surpreendeu é que a escola sabe, e é o que mais me irrita, é que a direção sabe dessas questões, não é nada feito escondido [...]. Essas falas são comentadas na sala dos professores, no conselho de classe e a direção em nome da perpetuação de seu poder, se cala. E o mais impressionante é que a escola se cala e afirma que não há preconceito - quer dizer, não há preconceito em uma professora entrar e falar um monte de coisa, e ela falou isso outras vezes, na frente de outros colegas, de que "ah! Eu entrei naquela sala e vocês sabem né, ficou tudo escuro porque só tem preto na sala", e a escola afirma que não existem problemas de questão racial. [...] eu acho que a escola como instituição não pode ser reprodutora de preconceitos e eu acho que cotidianamente a escola faz isso e é isso que me incomodou e hoje me incomoda tanto [ao ponto] de eu não acreditar que a escola vai resolver isso, não acredito que a atual direção ela se dê conta e queira trazer tal discussão. E há pouquíssimos parceiros, porque se eu já não era simpática hoje eu sou menos ainda, teve uma colega que falou "chegou a inimiga número um [do colégio]" sou eu né, dificilmente vou estabelecer parcerias para desenvolver um trabalho diante do que foi falado. (Professora 5, setembro de 2009)

Esta situação relatada, que nos anos seguintes levou à saída da professora daquela escola, pela insustentabilidade das relações, interfere diretamente na prática curricular docente e na implementação da Lei 10.639. O esfacelamento de solidariedades a partir da instauração destes conflitos, cujo objeto eram os comportamentos dos agentes e o tratamento da direção no tocante às relações raciais no cotidiano escolar, tensionados pela professora - que neste momento se posiciona como sujeito da construção de uma educação antirracista - municiada pela Lei 10.639, levou a docente a sair da escola. Antes de sua saída, obviamente, tal clima de isolamento interfere não apenas nas disputas que ela realiza pela implementação da Lei 10.639 junto a outros sujeitos, mas também no seu próprio trabalho na disciplina de Geografia, visto que as suas relações com alunos também são influenciadas pela forma como se relaciona com o professorado e a coordenação ${ }^{8}$. Assim, podemos inferir que a

\footnotetext{
${ }^{8}$ Como é mostrado em seu seguinte depoimento: [...] sempre fui perseguida na escola pela direção e por um grupo de professores e então o que a gente procura fazer dentro da escola? A gente procura fazer o nosso melhor. A gente procura não chegar atrasado, não faltar, dar os conteúdos e ter uma boa relação com os alunos, porque... assim... qualquer deslize nosso, vão falar "Aquele bando de gente que só vive falando da questão de negro" (Professora 4, setembro 2009)
} 
constituição de "alianças" se torna uma necessidade fundamental para o protagonismo na implementação da Lei 10.639 no cotidiano escolar.

Tal necessidade de constituição de alianças apareceu de maneira mais sublinhada nas situações em que o objeto em disputa no conflito eram atividades e eventos trans, multi ou interdisciplinares - sobretudo, mas não apenas, em torno da incorporação do dia 20 de Novembro no calendário escolar, na forma da construção de semanas que tratassem a temática racial de maneira integradora. Sendo momentos de negociação em que os(as) docentes eram "obrigados" a se reunirem com seus pares e com a coordenação, as diversas visões de mundo se chocavam, fazendo com que os posicionamentos políticos e ideológicos aparecessem na forma de discursos enunciados ou de comportamentos de negação dissimulada. Vejamos o seguinte depoimento:

Então, o que acontece... esse mês, esse bimestre, passou muito rápido e não deu para fazer muita coisa não. Na verdade, o que aconteceu, é que a gente tinha elaborado um projeto, não sei se vocês lembram. Sobre trabalho, ética, colocar profissionais negros que fossem oriundos de escola pública pra poder servir de exemplo pra garotada lá e tal, porque eles mesmos não acreditam que podem ir muito longe, isso foi relato deles mesmos. Então a gente ia pegar esse projeto e tocar, mas só que esse projeto foi substituído por projetos relacionados a meio ambiente, aí quando eu perguntei à direção "por que vocês fizeram isso, o projeto estava tão legal e tal", aí eles "Não, porque o terceiro bimestre está muito curto, então a gente vai passar isso pro quarto, então a gente vai colocar um troço mais simples agora". Aí eu falei: "Geralmente o quarto (bimestre) é mais curto do que o terceiro". Aí eles disseram "Se não der para fazer nesse, nós fazemos no início do ano que vem". Então na verdade (risos)...Eles vão empurrando com a barriga. O grande lance é que está chegando o dia 20 de Novembro aí, e aí eles não têm como escapar de um projeto relacionado à questão negra, então a gente vai procurar trabalhar e elaborar um projeto voltado mais para 20 de Novembro, porque aí a gente deixa os caras de "calçacurta” e não tem como eles fugirem da discussão. (Professor 2, setembro 2008)

$\mathrm{Na}$ situação narrada pelo professor, a direção da escola não enuncia um posicionamento contrário à atividade proposta por ele, ou seja, não explicita uma posição "contra", mas ao protelar a realização da atividade e propor outras, concorre para o esvaziamento da temática e a não implementação da Lei 10.639. A não explicitação de posicionamento, somada à utilização de um argumento de natureza burocrática (considerado falso pelo docente), constitui uma modalidade de comportamento típico do que Camino et. al. denominam como "novo racismo", padrão que, diante da emergência da crítica e legislações de coibição ao racismo, tem o núcleo 
de sua prática "constituído, por um lado, pela afirmação de valores igualitários (...) e, por outro lado, pela oposição (...) a políticas congruentes com os valores igualitários" (pg. 15). Ao invés de manifestações abertas de sentimentos e atitudes discriminatórias, este "novo racismo" comporta formas sutis, dissimuladas, veladas, de maneira a se esquivar do conjunto de restrições institucionais e legais às práticas discriminatórias baseadas nas diferenças de raça. Uma delas é a "sabotagem" às ações de combate ao racismo ou aos seus impactos - mas sempre, em nome da igualdade, tratada como um pressuposto idealizado e não algo concreto a ser alcançado através de medidas efetivas. Isso aparece também no seguinte depoimento:

Vamos lá, na escola estadual eu continuo enquanto coordenação pedagógica e desde o final do ano passado a relação estava ficando um pouco conflituosa, e esse ano está mais ainda, está bem complicada a relação. Por conta de que no final do ano passado a direção resolveu que iria ter projetos por área. E aí coube para a área de Geografia, História, Sociologia e Filosofia o Dia da Consciência Negra. E aí no início do ano, em reunião por área, foi apresentado isso, na linha do que a direção tinha colocado, e assim... Tive que fazer isso, coisa que eu não sou, enfim... Não consegui convencer na reunião. Mas é isso, e aí tem que fazer. Não foi uma discussão, foi uma decisão. E enfim, dos professores que tinham participado da reunião por área foi tranquilo, eram os professores de História e Geografia. Não tinha ninguém de Sociologia e Filosofia. E aí tiraram umas linhas iniciais de como seria o projeto, ali eles definiram o que iriam fazer durante o ano, tentar... eu tinha dado essa sugestão e eles ficaram de tentar dentro dos conteúdos, que no início da reunião eles fizeram com base na proposta que a Secretaria Estadual mandou sobre o currículo, todas as áreas lá, todos os professores resolveram pegar a base curricular e discutir em cima disso. Não quiseram fazer nada diferente e enfim, teve área da escola que: "não, tá ótimo!" e teve área que: "não, aqui tá ruim..." E aí eles fizeram isso, e dentro do que eles definiram dos conteúdos eles iriam buscar temas que pudessem trabalhar no sentido de dar a consciência do porquê do dia 20. Então o tema que eles sugeriram é: "Resistência Negra - O Porquê do dia 20 de Novembro", esse é o tema que cada área vai trabalhar. Só que não tinha ninguém de Sociologia e nem de Filosofia. E aí definiram de culminâncias as atividades: vai ter mostra de vídeos, tem o professor de Geografia que se formou na FFP [Faculdade de Formação de Professores da UERJ] "Fulano"... E aí, tinha marcado uma outra reunião, e já ampliando para que os professores de Filosofia e Sociologia estivessem, para poder passar o que o pessoal de História e Geografia tinha definido. E foi aonde foi o conflito. Que uma professora de Filosofia, que eu já tinha relatado que ela dá aula de código de trânsito na aula de Filosofia, ela virou e falou que era contra o dia 20 , que não concordava, mas que já que era uma coisa definida, ela não ia mesmo conseguir reverter isso não é? Mas que ela não ia fazer nada! Aí eu fui puxar a discussão do porquê? Então ela veio com um discurso que tem que trabalhar a diversidade: onde ficam os indígenas, os brancos, e enfim... Não ficou uma coisa muito boa. E virou o professor de Sociologia, o "Beltrano", que pela direção da escola é um ótimo professor, é o 
professor que não deixa de dar aula, que não falta... O cara vira primeiro antes de começar a reunião, pergunta se não podia fazer essa reunião num outro dia. Só que eu tinha marcado essa reunião com muito tempo de antecedência para que os professores se programassem, porque sem os dois últimos tempos de aula. Só que o cara não vem a nenhuma reunião se marcar no final de semana ou qualquer outro dia que ele não dá aula. Eu marquei a reunião na sexta porque a maioria dos professores de Filosofia e Sociologia estão na sexta, e começou assim. Como tinha apresentado a sugestão de tentar trabalhar os conteúdos, ele foi e veio com um discurso todo acadêmico de que estava sendo reducionista, porque até a visão das ações afirmativas é algo que vinha a partir dos Estados Unidos, aí pronto... Acabou tudo né. Aí ficou o diálogo com ele, só que tinha outros professores. Tinha uma professora de História nova na escola, se formou na UFF, mas tinha um contato bom com o pessoal de Quilombo, ela trouxe um material que eu não tive tempo ainda de olhar, me deu duas cópias de DVD que eu tenho que ver, mas se mostrava interessada querendo assim, meio tímida, eu senti que ela queria fazer um discurso mas ela estava meio tímida, então ficou aquela coisa: Eu só dialogando. Os outros professores tipo: concorda e tal, vão fazer... E até o ponto que eu cheguei: "E com exceção da "Fulana" [professora de Filosofia] que não vai fazer nada..." Mas é assim, mulher do vice-diretor, faz o que quer na escola. Ela de certa forma joga contra, foi uma que espalhou na escola que a UERJ estava formando turmas só de cotistas, para ser contra as cotas. Porque eu tinha feito um debate com os terceiros anos no início do ano sobre vestibular, falando de ações afirmativas, que os alunos na verdade não tem informação, então eles ficam formando ideias de coisas que eles não têm e aí fui esclarecer. E eu acho que deve ter isso. Acho que ela foi falar, e espalhou isso na escola, espalhou isso na turma, que a UERJ estava formando turmas só para cotistas e por isso era contra. Que uma professora amiga dela foi convidada para dar aula pra essas turmas. Eu não aguentei, disse que não. Que isso é mentira. Que é um absurdo. O problema é reverter isso (Professora 3, abril de 2010)

Este padrão de debates, em que discursos universalistas de igualdade são mobilizados contra a implementação da Lei 10.639, ganha em complexidade quando, ao invés de uma "arena" em que dois ou mais sujeitos se colocam antagonicamente, numa situação que aqui estamos chamando de "embate", se dá no âmbito da própria visão de mundo que epistemicamente serve de base para a construção dos conhecimentos que integram os conteúdos praticados nas disciplinas. O choque entre conteúdos tratados por diferentes professores pode constituir um “conflito (aparentemente) sem arena”, ou, sem a presença dos dois interlocutores em antagonismo. Vejamos uma situação vivenciada por um dos docentes:

Eu tentei exatamente fazer a grande virada lá na questão dos conteúdos trabalhando em sala. (...) Na oitava série eu tentei com duas turmas, mas do que eu realmente senti falta foi do material didático, porque, como assim... Eu já tinha começado a discussão, mesmo sabendo que o autor [do livro didático] lá 
já tinha dito que não era pra tocar no período anterior, tinha que vir numa nova forma... Como eu já tinha começado, eu fui tentar fazer o bate-bola, o pinguepongue de tentar apontar diferenças de um lado e de outro, formas de visão de mundo etc. E aí, alguns alunos conseguiram pescar a discussão, outros assim ficavam olhando pro livro, olhava pra mim e falavam "pô, mas em História a gente trabalha diferente"... Assim, eu acho que é uma coisa que a gente tem que começar a se preocupar mais com a produção de material didático... Porque a gente acaba ficando numa sinuca de bico assim, porque fica a minha fala contra o livro, contra a aula de História e aí a gente fica numa sinuca de bico. Eu acho que deu pra introduzir a discussão, muitos ficaram mais ligados, outros nem tanto, mas assim, eu acho que a questão do material didático é uma coisa que a gente tem que pensar assim é... Fazer tipo assim, um livro de geografia do "B" né, assim... Ter tipo uma contrapartida, um material que a gente possa usar, um texto, um mapa, qualquer coisa diferenciada assim, e aí eu acho que... Ajuda na discussão, até mesmo porque, por exemplo, na maior parte das vezes a gente pode até trabalhar diferenciado né, distante, mas assim, a aula de História não é, então assim de repente a gente pode usar como contraponto mesmo da aula de História, ou até mesmo na comparação, que até mesmo é uma forma equivocada segundo aqueles textos que a gente leu, mas assim, é uma forma de se estar trabalhando também. E aí tentar utilizar como contraponto pra você botar o moleque pra olhar, pensar e refletir, eu acho que é isso assim... (...) Mas assim, é uma forma de olhar, é uma forma de ver, a gente tem que ver todas as visões...Mas assim, algumas vezes eu fui indagado na questão assim, "o livro didático é a aula de história", "mas a professora de história falou assim", "o professor falou que no livro tá mostrando assim", eu falei assim, "não, tudo bem, isso é uma outra visão que eu estou trazendo, pra gente ter uma noção". Também eu não aprofundei muito porque eu senti que complicaria pra eles, pela experiência deles mesmo.

\section{- Qual discussão você fez com eles?}

- Eu estava trabalhando a questão da organização do espaço em países desenvolvidos e subdesenvolvidos, focando nos países desenvolvidos e mostrando o porquê desse desenvolvimento em relação aos demais. É a questão da exploração do trabalho, em relação ao trabalho, indo muito nessa linha... E aí eu fui buscando algumas coisas na leitura, mostrando aquela questão da organização, que os negros é que... A divisão internacional do trabalho representa não só uma divisão econômica, mas também uma divisão racial, mostrando que isso é uma tentativa de organização, e aí eu fui seguindo nessa linha. (...) Mas assim, eu fui mais ou menos por essa linha e aí foi legal a discussão né, eu acho que foi bem legal, mas muitos tem aquela visão do econômico como eu tenho também, como eu já tinha dito, muito marcado então assim, segurando... "Não pô, mas e a questão econômica, assim...", eu, "não, calma gente, vamos lá"... Aí tentando puxar. A discussão foi legal, não foi ruim não, mas eu acho que a gente tem que pensar mais em material didático, mas não só filmes né, texto, qualquer coisa assim para usar de contraponto mesmo caso seja necessário ou você utilizar ele sozinho, você elimina o livro e usar ele sozinho, eu acho que a gente tem que pensar alguma forma de produzir tal coisa. Minha experiência foi essa. (Professor 1, Setembro 2008) 
A complexidade da crítica racial no tratamento dos conteúdos, visando a implementação da Lei 10.639, neste depoimento, coloca o docente numa rota de colisão com o ensino praticado de História para a mesma turma. O potencial risco de desencadeamento de um conflito (e, com a possibilidade da personalização) com o professor de História, a depender da maneira como tal crítica chegar a ele, nos evidencia essa complexificação.

Os depoimentos acima evidenciam como as(os) docentes em suas atividades dentro e fora do ambiente da sala de aula disputavam a introdução do debate na escola, nos impondo uma interpretação mais complexa da implementação da Lei 10.639 que, mobilizada enquanto um artefato político, faz com que a rotina construída no cotidiano escolar seja tensionada pela luta antirracismo. Assim, alguns questionamentos (em complemento aos já realizados, e que não temos aqui a pretensão de responder) ganham relevo: Por que a mudança na forma de tratamento da temática racial gera tantos embates e dilemas? Como essas interações influenciaram nas vivências cotidianas desses professores? Qual é o rebatimento em seus currículos praticados?

\section{CONSIDERAÇÕES FINAIS: O COTIDIANO ESCOLAR E O ENSINO DE GEOGRAFIA - PALCO DE CONFLITOS E CAMPOS DE DISPUTA}

A leitura das interações vividas no cotidiano escolar por docentes buscando implementar a Lei 10.639 nos obrigam a considerar a indissociabilidade entre saber e poder. Com efeito, ao tratar os temas trazidos pela Lei, o conjunto de docentes observados rompe, necessariamente, com cânones estabelecidos nas tradições hegemônicas de currículo, tanto no tocante a conteúdos quanto a práticas. Emergem, assim, as relações vividas por eles, como centrais para uma leitura do cotidiano como organizado/constituído por operações de saber-poder. Aqui, vimos como o imbricamento entre saberes e poderes, quando estes são interrogados, implica na configuração de padrões de conflitividade.

As situações relatadas de conflito, ao derivar tanto de agires "individuais" (como p ex, uma mudança na abordagem de um conteúdo na própria disciplina de Geografia ministrada por um docente) quanto de tentativas de coletivização de ações ( $p$ ex, numa proposição de uma atividade em torno do Dia da Consciência Negra), nos mostram 
como as estruturas presentes no cotidiano escolar são complexas, configurando contextos e interações que acabam construindo campos, tipos e espaços de interações, que consequentemente re-funcionalizam a própria estrutura da escola. $\mathrm{O}$ entrecruzamento de campos de disputa ( $\mathrm{p}$ ex, o tratamento da temática racial e a direção da escola) embaralha posições, tornando pouco explicativa qualquer simplificação de posições. Entretanto, o que os casos apresentados e o acompanhamento realizado ao longo de cinco anos com o conjunto de docentes nos apontam que, por mais que seja prudente relativizar posições "a favor" e "contra", o que ainda predomina são forças inibidoras das transformações curriculares impulsionadas pela Lei 10.639.

Tais forças inibidoras se manifestam através de diversos padrões de comportamentos - como aparece exposto em parte, em depoimento da Professora 4, que em novembro de 2009, relatou que ao adentrar a sala da colega de profissão para dar informes sobre uma feira étnico-cultural que iria ocorrer no colégio, observou a mesma fazendo cartazes sobre a temática racial - trabalho que cabia aos estudantes, em caráter de pesquisa -, e alegou que, por não acreditar na existência do racismo, preferia ela mesma fazer a atividade do que deixar que os estudantes a fizessem. Ou do professor de inglês, que por também não acreditar no racismo, falou que após a atividade iria dizer que não existe racismo no Brasil ${ }^{9}$. Estas atitudes evidenciam que existe uma pulverização das resistências ao antirracismo no cotidiano da escola. Nas disputas cotidianas pelo combate ao racismo no ambiente escolar, um conjunto de relações de poder-saber tem interlocutores que, através de suas práticas, acabam acomodando as estruturas já construídas nesse ambiente.

É importante ressaltar que esse tipo de posicionamento é ratificado por um acordo tácito existente em grande parte das escolas, bastante presente no processo de invisibilização dos conflitos de ordem racial, como visto no caso da professora 5 , que como expusemos anteriormente - devido a conflitos com outros professores e com a direção - precisou sair da escola que trabalhava em Bangu, para uma nova escola em Lins de Vasconcelos.

\footnotetext{
${ }^{9} \mathrm{E}$ aí quando eu falei pra ele [um professor] do que se tratava o filme, ele falou assim "Bem, já que você está aqui, você vai ficar, mas vou falar pra minha turma: no Brasil não tem racismo!”, [...] Olha, foi uma confusão, aí eu o deixei ele falando, não vou discutir na frente das crianças... "mas você permite que eu passe o filme?", aí ele disse "permito", então ele ficou o tempo todo lendo e não viu o filme. Você acredita num negócio desse? (Professora 4, Novembro 2009)
} 
Assim, essa articulação legitima politicamente (GOFFMAN, 1985) determinadas ações, ao mesmo tempo em que impede que novas práticas sejam engendradas. Com isso, este ambiente deixa de ser o lugar do novo, do diferente, ou o palco do exercício e da liberdade pedagógica como é visto em diversas leituras sobre o cotidiano escolar, pois ao congelar esse cenário, se normatiza um conjunto de saberes e práticas passiveis ou não de serem implementadas.

Ao seguir essa lógica, é viável dizer que ao mesmo tempo que essas interações constroem o currículo, elas são construídas/alicerçadas por ele. O currículo enquanto campo de/em disputa apresentam diferentes dimensões, com múltiplos atores que dependendo dos contextos de interação podem concordar ou discordar das proposições. Nessa perspectiva, as práticas cotidianas na disputa pela implementação da temática racial, também são permeadas por outros campos de disputa - que podem acontecer dentro e fora da escola.

Cabe ressaltar que é através do conjunto de interações (e consequentemente práticas) ocorridas no cotidiano escolar, que o currículo ganha forma e serve para promover ou romper com as relações de poder-saber, construídas para legitimar diversas hierarquias sociais, como a de raça, gênero, sexualidade etc. À vista disso, as interações presentes no cotidiano escolar, em ligação com o currículo praticado, são campos de leitura e de ação, para lutar contra as influências diretas e indiretas que a Geografia que se ensina sofre.

A leitura aqui proposta confere aos(às) professor(as), e ao seu currículo praticado, um protagonismo na luta contra o racismo no cotidiano escolar. Tal interpretação nos permite observar que à medida que as professoras e professores implementam em seus cotidianos outras práticas (teóricas-conceituais e no campo do tratamento dos indivíduos) que não as "tradicionais", acabam mexendo com as práticas, as hierarquizações, e as próprias relações de trabalho até então acordadas e naturalizadas. Ao discutir hierarquias e privilégios, os professores e professoras acompanhados/as estão rompendo com essa articulação e ao fazer esse movimento tensionam a continuidade desse padrão de relações. Rompem, pois ao complexificar a leitura da lei 10.639/03, levam para o cotidiano escolar, por exemplo, diversas discussões e debates que questionam o que é nele construído, ao mesmo passo questionam as práticas pedagógicas e os conteúdos tradicionalmente aceitos. Em um 
ambiente onde os saberes já estão acomodados e ratificados pelos diversos acordos, isso acaba por pressionar ordenamentos das relações presentes no ambiente escolar.

Ou seja, ao tentar implementar no currículo escolar uma interpretação da Lei 10.639/03 construída no/pelo Movimento Negro, interpretação essa que não é o hegemônico nas políticas públicas de Estado, ou dentro da linha de quem escreve e concebe os livros didáticos, ou como se pode ver através de alguns relatos, entre as/os colegas de profissão, as/os professoras(es) acompanhados/as começam a levar para dentro do cotidiano escolar as visões desse movimento social que historicamente luta contra o racismo.

Por fim, destacamos que os desafios para a implementação de uma educação antirracista no ensino de geografia evidenciados através dos conflitos na prática cotidiana de professoras(es) nos indicam que além do currículo praticado ultrapassar o tempo-espaço da aula, ao introduzir uma nova lógica, essas(es) professoras(es) passam a ser essa disrupção da ordem até então estabelecida.

\section{REFERÊNCIAS BIBLIOGRÁFICAS}

ALVES, N. Decifrando o pergaminho - o cotidiano das escolas nas lógicas das redes cotidianas, 2001. Disponível em: $<$ http://coletivoepa.pbworks.com/f/Decifrando+o+pergaminho+-+nilda+alves.doc $>$ Acesso em: $15 / 02 / 2020$.

ARAUJO, T. F. de. Por uma Geografia dos outsiders: interpretação e aplicação da Lei 10.639 na rede municipal de Armação dos Búzios em sua relação com a comunidade remanescente do quilombo da Rasa. Monografia (graduação), Faculdade de Formação de Professores Universidade do Estado do Rio de Janeiro - FFP-UERJ, 2010, p. 90.

CALlAI, H. C. Aprendendo a ler o mundo: a geografia nos anos iniciais do ensino fundamental. Cad. Cedes, Campinas, vol. 25, n. 66, p. 227-247, maio/ago. 2005. Disponível em: http://www.scielo.br/pdf/ccedes/v25n66/a06v2566.pdf (Acesso em: 17 fev. 2020)

CAMINO, L., SILVA, P., MACHADO, A. \& PEREIRA, C. A face oculta do racismo no Brasil: Uma análise psicossociológica. Revista de Psicologia Política, 1, 2001. p.13-36.

CASTROGIOVANNI, A. C., GOULART, L. B. Uma contribuição à reflexão do ensino de geografia: a noção de espacialidade e o estatuto da natureza. n.7, p.109-118, 1990. Disponível em: http://www.agb.org.br/publicacoes/index.php/terralivre/article/view/87 (Acesso em: 17 fev. 2020)

CERTEAU, M. de. A invenção do cotidiano: artes do fazer. Petrópolis: Editora Vozes, 1994. "Introdução Geral" e primeira parte "Uma cultura muito ordinária" pp. 37-109 
CORREA, G.S. Narrativas raciais como narrativas geográficas: uma leitura do branqueamento do território nos livros didáticos de geografia. Niterói. Dissertação (Mestrado) - Universidade Federal Fluminense, 2013.

DINIZ, F. G. A formação contínua de professores de Geografia para implementação da Lei Federal $n^{\circ}$ 10.639/03 a partir de um projeto de pesquisa-ação. Dissertação (Mestrado) Universidade Federal do Estado do Rio de Janeiro, 2015.

ESCOLAR, M. Crítica do discurso geográfico. São Paulo: Editora Hucitec, 1996.

GIDDENS, A. A constituição da sociedade. 2 ed. São Paulo: Editora: WMF, 2003.

GOFFMAN E. Representações do eu na vida cotidiana. Petrópolis: Vozes; 1985.

JESSOP, B (2002). Globalização, regionalização, mercado e o Estado: entrevista com Bob Jessop. Currículo sem Fronteiras, v.2, n.2, pp.5-21, Jul/Dez 2002. Disponível em: http://www.curriculosemfronteiras.org/vol2iss2articles/jessop.pdf (Acesso em: 28 fev. 2020)

MACEDO, E. Currículo: Política, Cultura e Poder. In: Currículo sem Fronteiras, v.6, n.2, pp.98-113, Jul/Dez 2006 Disponível em: http://www.curriculosemfronteiras.org/vol6iss2articles/macedo.pdf (Acesso em: 19 fev. 2020)

MONTEIRO, G., VIEIRA, A, DINIZ, F. G. \& SANTOS, R.C. Oficina de Filmes e Relações Raciais: materiais para aplicação da Lei Federal no 10.639/03 no Ensino Básico. Revista Tamoios, v. 7, p.60-71, 2011. Disponível em: https://www.epublicacoes.uerj.br/index.php/tamoios/article/view/1708/2990 (Acesso em: 19 fev. 2020)

SANTOS, B. de S. Para uma sociologia das ausências e das emergências. Revista Crítica de Ciências Sociais, n.63, 2002, p. 237-280.

SANTOS, C. A. C. dos. Sob a névoa do norte: reflexões sobre colonialidade, "raça" e livros didáticos de geografia do ensino fundamental, Rio de Janeiro. Dissertação (Mestrado) Universidade Federal do Estado do Rio de Janeiro, 2013.

SANTOS, I. A. A. O movimento negro e o Estado (1983-1987). São Paulo: Prefeitura de São Paulo, 2006.

SANTOS, R. E. dos. O ensino de Geografia do Brasil e as relações raciais: reflexões a partir da lei 10.639. In: SANTOS, (Org.). Diversidade, espaço e relações sociais: o negro na Geografia do Brasil. Belo Horizonte: Autêntica, 2007 (3ª Ed, 2013).

SANTOS, R. E. dos.; CORRÊA, G. S.; SANTOS, R. C. Oficinas -racismo e educação: experiências de atuação de uma pesquisa-ação na aplicação da lei 10.639/03. e-Mosaicos, v. 7, p. 125-140, 2019.

SANTOS, R. E. dos. A Lei 10.639 no PNLD de Geografia: um ensaio sobre questões, mudanças e permanências. In: Tonini, I. M.; Goulart, L. B.; Kaercher, N. A.; Martins, R. M.; Costella, R. Z. (Org.). Geografia e livro didático: para tecer leituras de mundo. 1ed.São Leopoldo: Oikos, 2018, v. 1, p. 29-49. Santos, 2012

SANTOS, R. E. dos s. A Lei 10.639 e o Ensino de Geografia: construindo uma agenda de pesquisa-ação. Revista Tamoios, v. 7, p. 4-23, 2011 b. 
SANTOS, R. E. dos . Movimentos Sociais e Geografia: Sobre a(s) espacialidade(s) da ação social. 1. ed. Rio de Janeiro: Consequência, 2011a.

SANTOS, R. C. Relações de poder na construção do currículo praticado: uma análise de conflitos na prática cotidiana de professores na implementação da Lei 10.639 no ensino de geografia. Dissertação (Mestrado) - Universidade do Estado do Rio de Janeiro - Faculdade de Formação de Professores, 2017.

SANTOS, S. A. “A Lei 10.639/03 como fruto da luta anti-racista do Movimento Negro”. In: (org.). Educação Anti-racista: caminhos abertos pela Lei Federal no 10.639. Brasília: Ministério da Educação, Secretaria de Educação Continuada, Alfabetização e Diversidade, 2005.

SILVA, T. T. da. Documentos de Identidade: Uma Introdução às Teorias de Currículo. $3^{\circ}$ Edição. Editora Autêntica. 2010.

ROCHA, G.H.C. . Discutindo a influência das organizações e dos habitus religiosos sobre a prática do professor de geografia: fatores que regulam o currículo praticado. Monografia (graduação), Faculdade de Formação de Professores - Universidade do Estado do Rio de Janeiro - FFP-UERJ, 2011.

TONINI, I. M. Identidades capturadas: gênero, geração e etnia na hierarquia territorial dos livros didáticos de geografia. Porto Alegre, 2002. Dissertação (mestrado) Universidade Federal do Rio Grande do Sul.

Recebido 28/02/2020

Aprovado em 30/03/2020 